\title{
Management of Root-Knot Nematode, Meloidogyne graminicola in Rice Using Bacterial Strains
}

\author{
Ram Sharan $^{1 *}$, Gurpreet Singh ${ }^{1}$, Rajkumar $^{2}$ and Sumit ${ }^{2}$ \\ ${ }^{1}$ Department of Nematology, CCS HAU, Hisar-125004, Haryana, India \\ ${ }^{2}$ Department of Agricultural Economics, CCS HAU, Hisar-125004, Haryana, India \\ *Corresponding author
}

\begin{tabular}{|c|c|}
\hline & A B S T R A C T \\
\hline $\begin{array}{l}\text { Ke y w or d s } \\
\text { Rice, M. graminicola, } \\
\text { Pseudomonas spp., } \\
\text { Gluconacetobacter } \\
\text { diazotrophicus, } \\
\text { Azotobacter } \\
\text { chroococcum, } \\
\text { Bacillus spp. }\end{array}$ & \multirow{3}{*}{$\begin{array}{l}\text { To study the effect of eleven strains of rhizobacteria, namely Azotobacter chroococcum } \\
\text { (103, MSX-9, HT-54 and BNR-6), Gluconacetobacter diazotrophicus (CO 99-70, 35-47 } \\
\text { and 760-50), Bacillus spp ( } 91 \text { and 65), Pseudomonas fluorescens and Pseudomonas } \\
\text { maltophila were used on rice (cv. PR-106) infected with Meloidogyne graminicola under } \\
\text { greenhouse conditions. Soaking of seed for five minutes in plain water was treated as } \\
\text { untreated check. After } 45 \text { days of sowing results indicated that all the rhizobacterial strains } \\
\text { significantly increased the plant height and weight and reduced the number of galls/plant } \\
\text { and multiplication of } M \text {. graminicola on rice significantly over untreated check, except } A \text {. } \\
\text { chroococcum strain } 103 \text {. Maximum plant height }(6.75 \mathrm{~cm}) \text { was recorded in } G \text {. } \\
\text { diazotrophicus strain } 760-50 \text { and B. spp. } 91 \text {. Similarly, maximum plant weight } 0.83 \mathrm{~g} \text { and } \\
\text { 0.93g recorded in both treatments, respectively. However, maximum reduction of } \\
\text { nematode population }(0.5 \text { and } 0.6) \text { times was observed in } G \text {. diazotrophicus strain } 760-50 \\
\text { and A. chroococcum strain BNR-6, respectively over untreated check (1.5). }\end{array}$} \\
\hline Article Info & \\
\hline $\begin{array}{l}\text { Accepted: } \\
\text { 01 December } 2017 \\
\text { Available Online: } \\
\text { 10 January } 2018\end{array}$ & \\
\hline
\end{tabular}

\section{Introduction}

Rice (Oryza sativa L.) is one of the most important among cereal crop in India. A remarkable achievement in food grain production after green revolution, transformed India from a net importing country in the mid1960s to exporter country in rice by the early 1990s. Rice is the world's most important staple food and is cultivated in around 162 million ha annually with an annual global production of 464 million metric tons (FAO, 2013)

The cultivation of rice is affected by several biotic and abiotic stresses. A number of ecto and endo-parasites of root, stem and foliar parts e.g., Aphelenchoides besseyi, Ditylenchus angustus and Hirshmanniella spp. have been already reported as major pests of rice from India (Prasad et al., 1987). Rice root-knot nematode, Meloidogyne graminicola is a pest of international importance and it is reported to cause $17-30 \%$ yield loss due to poorly filled kernels (Mac Gowan and Langdon, 1989) while in India nematodes of rice alone cause 10.54 per cent yield loss which causes monetary losses of 779.30 million rupees (Jain et al., 2007). 
Due to serious loss on rice yields, particularly under sub optimal management conditions and easy means of spread along with water and soil, there is a high potential to expand the infected area in the country by this nematode. The rice root-knot nematode, $M$. graminicola is being one of the major nematode pests in rice-wheat cropping system. Management of this nematode is need of an hour.

A number of practices are used for the management of this nematode. The chemical nematicides can effectively be used for their management but their use give rise to many serious problems viz. pollution, food contamination, environmental hazard and development of pesticidal resistance etc.

Due to these limitations of the hazardous chemicals, biopesticides of botanical origin and rhizobacteria with antagonistic potential have become the focus of attention today for managing the nematode problems which provide eco-friendly and low cost technology.

\section{Materials and Methods}

The experiment was conducted in green house of Department of Nematology, Chaudhary Charan Singh Haryana Agricultural University, Hisar. Eleven strains of rhizobacteria, namely Azotobacter chroococcum (103, MSX-9, HT-54 and BNR6), Gluconacetobacter diazotrophicus (CO 99-70, 35-47 and 760-50), Bacillus spp. (91 and 65), Pseudomonas fluorescens and Pseudomonas maltophila were used in the experimentation.

Untreated check (water dipped for 5 minutes) was maintained for comparison. All the strains had $1 \times 10^{7}$ spores $/ \mathrm{ml}$. Inoculation of the rhizobacteria was done by socking the seeds of rice with bacterial suspension in petri plates for five minutes. Treated seeds were sown in $15 \mathrm{~cm}$ earthen pots filled with one $\mathrm{kg}$ infested soil of Meloidogyne graminicola having initial population of 1.5 larvae/g soil. After germination, one plant was retained in each pot. There were twelve treatments and each treatment was replicated four times. Pots were arranged in completely randomized design. Observations were recorded after 45 days of sowing. The experimental data were statistically analysed by "Analysis of Variance" procedure as advocated by (Fisher, 1948).

\section{Results and Discussion}

The results in Table 1 indicated that out of eleven rhizobacterial strains tested, two strains namely, Bacillus spp. strain 91 and $G$. diazotrophicus strain 760-50 performed best in improving plant height significantly and maximally up to $6.75 \mathrm{~cm}$ in comparison to $4.50 \mathrm{~cm}$ in untreated check. Similarly these strains were also found to enhance fresh plant weight by $0.93 \mathrm{~g}$ and $0.89 \mathrm{~g}$, respectively in comparison to $0.38 \mathrm{~g}$ in untreated check. Among the A. chroococcum strains BNR-6 was found the only strain to improve plant height. However, rest of the three strains could not improve the plant height over untreated check. Among the $G$. diazotrophicus strains, 760-50 followed by CO 99-70 improved plant height and weight significantly.

None of Pseudomonas strain could improve plant height, however, plant weight was recorded to be significantly higher over untreated check in both the species. Jafri et al., 2015 also found positive effects of bacterial strain in improving tomato growth parameters against Meloidogyne incognita. Bacterial strains remarkably suppressed nematode infestations because they act as growth inhabiting agents for juveniles that stimulate metabolic activities in the roots causing root growth which also help plant to absorb more nutrients by causing root proliferation. 
Table.1 Effect of rhizobacterial inoculation on plant growth and number of galls on rice infected with Meloidogyne graminicola

\begin{tabular}{|l|c|c|c|}
\hline \multicolumn{1}{|c|}{ Treatments } & Plant height $(\mathrm{cm})$ & Plant weight $(\mathrm{g})$ & Number of galls/plant \\
\hline Azotobacter chroococcum 103 & $5.20(15.5)$ & $0.51(34.2)$ & $20.00(2.56)$ \\
\hline A. chroococcum MSX 9 & $4.55(1.1)$ & $0.49(28.9)$ & $13.75(-29.5)$ \\
\hline A. chroococcum BNR-6 & $5.50(22.2)$ & $0.59(55.3)$ & $9.25(-52.7)$ \\
\hline A. chroococcum HT-54 & $4.75(5.5)$ & $0.52(36.8)$ & $13.50(-30.9)$ \\
\hline Gluconacetobacter diazotrophicus Co 99-70 & $5.70(26.7)$ & $0.84(121.0)$ & $12.25(-35.9)$ \\
\hline G. diazotrophicus 35-47 & $4.75(5.5)$ & $0.41(7.9)$ & $10.75(-44.9)$ \\
\hline G. diazotrophicus 760-50 & $6.75(50.0)$ & $0.89(134.2)$ & $5.75(-70.5)$ \\
\hline Bacillus. sp. 91 & $6.75(50.0)$ & $0.93(144.7)$ & $12.75(-34.7)$ \\
\hline Bacillus sp. 65 & $4.75(5.5)$ & $0.45(18.4)$ & $16.00(-18.0)$ \\
\hline Pseudomonas fluorescens & $4.75(5.5)$ & $0.52(36.8)$ & $13.50(-30.8)$ \\
\hline P. maltophila & $5.25(16.6)$ & $0.62(63.2)$ & $14.75(-24.4)$ \\
\hline Untreated check & 4.50 & 0.38 & 19.50 \\
\hline CD at 5\% & 0.79 & 0.09 & 2.88 \\
\hline Figurs win
\end{tabular}

Figures within parenthesis denote increase (+)/decrease (-) over control

Table.2 Effect of rhizobacterial inoculation on multiplication of Meloidogyne graminicola in rice

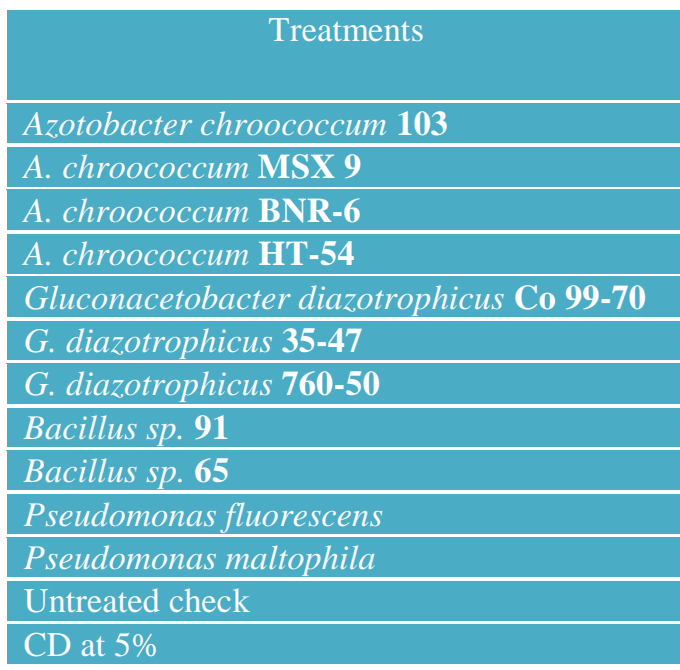

The data in Table 2 showed that except $A$. chroococcum 103, all the strains in general have significantly decreased root-knot nematode multiplication in rice ranging between $0.5-1.2$ times in comparison to 1.5 times nematode multiplication in untreated check after 45 days of sowing seed. Out of the ten effective rhizobacterial strains, $G$. diazotrophicus 760-50 was found most effective in reducing nematode population upto 0.5 times of initial population, followed

\begin{tabular}{|c|c|c|c|}
\hline \multicolumn{3}{|c|}{ Nematode population in } & \multirow{2}{*}{ R.f. } \\
\hline Root & Soil $\left(\mathbf{K g}^{-1}\right)$ & Total & \\
\hline 1062.5 & 890.0 & 1952.5 & 890.0 \\
\hline 800.0 & 700.0 & 1500.0 & 700.0 \\
\hline 318.8 & 595.0 & 913.8 & 595.0 \\
\hline 662.5 & 700.0 & 1362.5 & 700.0 \\
\hline 546.3 & 685.0 & 1231.3 & 685.0 \\
\hline 405.0 & 665.0 & 1070.0 & 665.0 \\
\hline 180.0 & 615.0 & 795.0 & 615.0 \\
\hline 726.3 & 645.0 & 1371.3 & 645.0 \\
\hline 1020.0 & 780.0 & 1800.0 & 780.0 \\
\hline 715.0 & 640.0 & 1355.0 & 640.0 \\
\hline 876.3 & 670.0 & 1546.3 & 670.0 \\
\hline 1450.0 & 810.0 & 2260.0 & 810.0 \\
\hline 309.4 & 147.5 & 374.5 & 0.2 \\
\hline
\end{tabular}

by $A$. chroococcum strain BNR-6 (0.6) and 35-47 (0.7). Among the isolates of $A$. chroococcum, BNR-6 reduced final nematode population at the end of the experiment. While G. diazotrophicus 760-50 was best among G. diazotrophicus strains, and Bacillus 91, P. fluorescens was found to be at par in reducing the final nematode population.

These results confirm the findings of Bansal et al., 2005. Our results are also in an 
agreement with Anita and Rajendran, 2005 who observed highest reduction in $M$. graminicola population in rice treated with rhizobacterial strain $P$. fluorescens. It seems that $G$. diazotrophicus 760-50 inoculation reduced root-knot disease severity by reducing the nematode population through reduced hatching by diminishing larval movement thus causing reduced entry/penetration of nematode juveniles into root.

\section{References}

Anita, B., and Rajendran, G. 2005. Effect of different methods of application of the growth promoting bacterium, Pseudomonas fluorescens migula on the management of Meloidogyne graminicola Golden and Birchfield, 1965 infecting rice. J. Biol. Control. 20: 233-236.

Bansal, R.K., Dahiya, R.S., Narula, N. and Jain, R.K. 2005. Management of Meloidogyne incognita in cotton, using strains of the bacterium Gluconacetobacter diazotrophicus.
Nematol. Medit. 33: 101-105.

FAO. 2013. Report of first session of the FAO. Panel of expert on Integrated Pest Control. Food and Agricultural Organization, Rome.

Fisher, R.A., 1948. The Design of Experiments. $5^{\text {th }}$ Eds. Oliver and Boyad, London.

Jafri, I., Shahid, A. A., Ibrahim, A. and Atif, M. 2015. Efficacy of different bacterial strains against Meloidogyne incognita. Pakistan Journal of Nematology, 33(1): 39-46.

Jain, R.K., Mathur, K.N., Singh, R.V. 2007. Estimation of losses due to plant parasitic nematodes on different crops in India. Indian Journal of Nematology, 37: 219-220

Mac Gowan, J.B., and Langdon, K.R. 1989. Hosts of the rice root-knot nematode, Meloidogyne graminicola. Nematology, 172:1-4.

Prasad, J. S., Panwar, M. S. and Rao, Y. S. 1987. Nematode problems of rice in India. Tropical Pest Management, 33: 127-136.

\section{How to cite this article:}

Ram Sharan, Gurpreet Singh, Rajkumar and Sumit. 2018. Management of Root-Knot Nematode, Meloidogyne graminicola in Rice Using Bacterial Strains. Int.J.Curr.Microbiol.App.Sci. 7(1): 3592-3595. doi: https://doi.org/10.20546/ijcmas.2018.701.421 